\title{
Writing the Haitian Earthquake and Creating Archives
}

\section{Rachel Douglas}

\section{OpenEdition \\ Journals}

Electronic version

URL: https://journals.openedition.org/coma/859

DOI: $10.4000 /$ coma.859

ISSN: 2275-1742

\section{Publisher}

Institut des textes \& manuscrits modernes (ITEM)

\section{Electronic reference}

Rachel Douglas, "Writing the Haitian Earthquake and Creating Archives ", Continents manuscrits

[Online], 8 | 2017, Online since 15 March 2017, connection on 12 January 2023. URL: http:// journals.openedition.org/coma/859; DOI: https://doi.org/10.4000/coma.859

This text was automatically generated on 12 January 2023

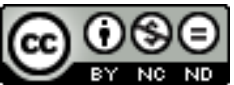

Creative Commons - Attribution-NonCommercial-NoDerivatives 4.0 International - CC BY-NC-ND 4.0 https://creativecommons.org/licenses/by-nc-nd/4.0/ 


\title{
Writing the Haitian Earthquake and Creating Archives
}

\author{
Rachel Douglas
}

\section{EDITOR'S NOTE}

Cet article est reproduit avec la permission expresse de la revue Caribbean Quarterly (Routledge, Taylor \& Francis Group). Mentions légales : « This permission is limited to nonexclusive print and E-Journal French language rights for this usage only. This permission does not cover any third party copyrighted work which may appear in the material requested. This license does not cover Taylor \& Francis content being republished in a custom publishing program or database. copyright ( $\odot$ University of the West Indies, reprinted by permission of Taylor \& Francis Ltd, www.tandfonline.com on behalf of University of the West Indies. »

1 How to tell the story of the Haitian earthquake? Ever since 4:53 p.m. on 12 January 2010 , this is the question many of Haiti's writers have been asking. In the face of such a catastrophe with widespread death, destruction and suffering, what can writers do? In terms of aftershocks, how have the thematics and representational form of Haitian writing developed in the wake of this seismic event? This article examines responses in Haitian writing to the earthquake through the prisms of a premonitory play entitled Melovivi ou Le Piège ( The Trap) by Frankétienne, and of chronicles and essays written by Dany Laferrière, Yanick Lahens and Gina Athena Ulysse, who, this article argues, react to threats to archives and material culture by creating a unique 'aura' of archival documents in the very form of their books themselves ${ }^{1}$.

2 In terms of archival matter, my reading is based upon the literary manuscripts of Frankétienne's play Le Piège, and Yanick Lahens's Failles (Fault Lines) and Guillaume et Nathalie $^{2}$. For the analysis of the actual manuscripts, this article exploits methodologies for studying literature in statu nascendi from genetic criticism-a predominantly French phenomenon, which has rarely been considered in the same context as postcolonial studies $^{3}$. Genetic criticism's methodology for studying the dynamics of stages of 
creation from first to final drafts of literary manuscripts is here extrapolated beyond the point of publication to the printed works. In the Haitian context, this article proposes that there is no clear-cut dividing line separating manuscript genetics from textual genetics; instead the transitions between the two zones are more blurred. Normally, the cut-off point for genetic critics falls at the publication of the text, but my approach to Caribbean and Haitian literature also considers multiple printed versions of the works in question.

3 In previous work, I have shown that rewriting is one of the foundational pillars of Caribbean literature 4 . Here, I explore how that process of rewriting is linked with another: that of archivisation, through which chronicles and essays on the Haitian earthquake try to preserve what remains ${ }^{5}$. Archival and rewriting impulses highlight a preoccupation with Haitian archives in written works that seek to produce them textually as well ${ }^{6}$. In the Haitian context, these archive stories and rewriting practices are at their most highly concentrated because the stakes and the scale of the destruction are more widespread and catastrophic. Caribbean writers, especially in Haiti, had always been archivists preoccupied with "saving the word" long before the earthquake struck and the cultural search and rescue operations began. As for rewriting, this is a process to which almost all authors subject their literary texts. Yet, while all writers rewrite to some extent, Caribbean, and particularly Haitian, writers subject their own texts and essays to a near-obsessive degree of rewriting. My argument is that these rewriting and archival impulses have become even more concentrated since 2010, and nowhere more so than when they are shaping and reshaping the accounts of the Haitian earthquake which are examined here.

4 This article contributes to debates around archives by suggesting that gaps and silences in the colonial archive, as identified by Michel-Rolph Trouillot in Silencing the Past: Power and the Production of History, are now increasingly being actively and transitively challenged and filled in by the emergence of new postcolonial archival-type writing? This article builds especially on the approach of Laurent Dubois, who puts historians and novelists in the French Caribbean (Guadeloupe) in dialogue, discussing how Guadeloupean creative writers use "archives in the fiction", highlighting what is missing from archives in this context by using the archive itself as a literary form in their work ${ }^{8}$. However, this emphasis on fiction does not quite the the Haitian earthquake narratives discussed here, many of which concern non- fiction and the recounting of real events.

5 It will be argued that much recent Haitian writing responds to a perceived state of being en mal d'archive-in need of archives-which is even more acute than that described by Derrida in Archive Fever, given the recent destruction by the earthquake of so many physical archival records and library/literary holdings. To be "en mal d'archive", according to Derrida, "is to burn with a passion. It is never to rest, interminably from searching for the archive, even if there is too much of it, right where something in it anarchives itself ... It is to have a compulsive, repetitive and nostalgic desire for the archive9". Derrida's archive theories are pertinent as a guiding framework through which to interpret the archive and postcolonial contexts in Haiti ${ }^{10}$. And yet, the level of abstraction and the lack of referentiality in Derrida's archive theories mean that these need to be supplemented by alternative perspectives on the archive and postcolonial contexts by Michel-Rolph Trouillot, and especially Achille Mbembe, Stuart Hall and Laurent Dubois, whose works transform the decontextualised 
emphasis of French criticism in my readings of Haitian archive stories and reading practices $^{11}$.

6 According to Martin Munro's masterful account of Haitian literature written in the aftermath of 2010, recent Haitian essays bear comparison to the Latin American crónica, described by Mark Anderson as a "brief hybrid essay combining personal observation with social documentary"12. Munro observes that the crónica was significantly one of the literary genres adopted by intellectuals following the 1985 Mexico earthquake, with Haitian essays harnessing a similar provisional form for engaging with pressing concerns about reconstruction following the Haitian quake. This perspective is advanced in the present article by my argument about the coming together of form and content in different archival incarnations. My focus turns more squarely to archives, and to the particular need for archive stories in Haiti to accompany these processes of becoming: narratives about how archives-in-the-making connect with literature- inthe-making in the face of the destruction of archives of all sorts in 2010 (historical, literary and artistic).

7 This earthquake dramatically reconfigured Haitian libraries and archives, including the Bibliothèque nationale d'Haïti, the Archives nationales d'Haïti and Haitian university libraries, which suffered some damage ${ }^{13}$. Most literary archives in Haiti have no repository or architectural dimension. For the most part, they have not been deposited with a national library, but are instead physically located in the writers' own private homes. This is certainly the case for Frankétienne's and Lahens's manuscripts. Frankétienne's house was badly damaged in the earthquake; however, the bookshelves were relatively unscathed. Yanick Lahens in her earthquake chronicle Failles recalls bookshelves falling, and also the fragility of the yellow notebooks containing her novelin-the-making Guillaume et Nathalie. The manuscripts of both Frankétienne and Yanick Lahens are surviving archives of the Haitian earthquake. They are private documents which do not have the status of official/institutional archives, but they are material testaments to, and remnants of, the debris of the earthquake. Works like Failles and Le Piège were handwritten and typed along the archival fault lines, and document the developing moment of the earthquake. These Haitian archives have not yet been packaged for mass consumption, although their authors are keen to preserve and disseminate further the rough workings of how their œuvre took shape before, during and after the earthquake as records of that past for the future. It is hoped that possibilities offered by digital media will enable accessibility. Already some of these works have been published in multiple editions with variations, especially Laferrière's Tout bouge autour de moi, giving readers the impression of reading different drafts of the book. These book-archives are not, however, explicitly labelled as such.

If we can shift from seeing archives only as inert historical collections, stable repositories of material, depositories of documents, or just as places, buildings and storage stations, or as symbols of public institutions, then archival work can also be seen as a process, with Haitian writers as integral parts of this archive storytelling. This view of archives resonates with Stuart Hall's comments about constituting a living archive of the diaspora: a process which is always unfinished and active ${ }^{14}$. Like Hall's living archive of the diaspora, any fantasy of completeness in these Haitian bookarchives is denied, and the archive can always be reread and rewritten in the light of the present and future. This continuous relational and dialogic process of archival production represents complex processes of creative invention, and a challenge to the 
basic assumptions of archival fixity and materiality. When these writers create archives in book form, they prevent them from becoming dead matter, and make them into a living memorial instead. Alternative visions require alternative archives, and what is foregrounded are the dynamics of refiguring such a vision.

9 As argued, these Haitian writers can be understood as creating postcolonial archives by unsilencing the past and the present in an active and transitive process of filling in the gaps and silences in official records, sources and narratives with new archival practices of rewriting, multiple narratives and editions, and the evocation of manuscripts and archives within the novels. These archival investigations now need to turn to the publishing history of these works. On the impact of colonialism and neo-colonialism on African and Caribbean publishing, Robert Fraser's comparative book history has examined the introduction of printing presses and the spread of books along with colonial rule ${ }^{15}$. Certain African and Caribbean writers, including George Lamming and Ngũgi wa Thiong'o, have written of the strong neo-colonial dimensions of exporting local works as raw materials ${ }^{16}$. Graham Huggan and Sarah Brouillette have pointed to the exoticised commodification of cultural difference in the packaging and marketing of postcolonial books ${ }^{17}$. Gail Low has highlighted the traffic between local and metropolitan publishing in book history related to the Anglophone Caribbean, and, most recently, Ruth Bush has taken similar investigations to the publishing contexts of Francophone African literature, particularly from the point of view of Paris and the French literary system ${ }^{18}$. Little has been done on Haitian book history, but this has the potential to be a fascinating topic, especially when considered from the perspective of the aftermath of the 2010 earthquake.

When Haitian publishing is taken into account, it unsettles any homogenised and monolithic view of Paris as a centrifugal literary hub. The supposed dominance of universalising metropolitan publishing houses and literary institutions in Paris must be considered in these discussions of alternative Haitian archives. Unsurprisingly, major Parisian publishing houses are now increasingly important metropolitan mediators of Haitian and Francophone Caribbean literature and brokers of world literature written in French. However, it is worth exploring the dynamics of the publishing trajectory of Haitian literature because, until recently, Haitian writers, despite the quality of their writing, have not been published by the leading French publishers. Independent since 1804, Haiti has a long history of publishing independently from former colonial power France, but Haiti quickly became a centre of self-publication by the writers themselves; a Haitian publishing tradition that continues to this day. These self-publishers have often been the heaviest investors in Haitian literature, and these writers themselves were always already archivists of their own literary work, privately tending to the different versions, and publishing them in material form, sometimes actively choosing to produce smaller print runs and multiple versions. This gives the writers more autonomy over how to write and what to change.

11 A search for a global foreign readership in French is a major concern of Haitian writers, but in the Haitian context, the question of who exactly are the readers can be a difficult one to answer. Illiteracy rates in Haiti are high, with some estimates as high as 80 percent, while 90 percent of Haitians are monolingual Kreyòl speakers. In the local Haitian context, then, the readers of the French text and the Kreyòl text are the same, with literate Haitians finding the French text easier to read because they have been taught how to read and write in French. Writers such as Frankétienne continue to 
publish themselves à compte d'auteur to drive towards the local conditions and readers. This is partly the result of the relative paucity of local publishing outlets to support book production, but writers often still choose to self-publish first in Haiti before publishing the same work with metropolitan publishers in France or Quebec.

During the worst excesses of the 1957-86 father-and-son dictatorship of François "Papa Doc" and Jean-Claude "Baby Doc" Duvalier-a dangerous regime for writers and journalists-most Haitian writers left the country. The few who remained, like Frankétienne, would continue to publish themselves at Port-au-Prince printing presses: a local context with few publishing outlets. During this time, Quebec became the new alternative centre of Haitian publishing, while relatively few Haitians travelled to France. Ever since the 1960s, Quebec has remained the alternative metropolitan centre of the Francophone world of letters, creating some literary stars, most notably Dany Laferrière. After 1986, some Haitian writers returned to their native land and decided to publish locally. Rodney Saint-Éloi set up Éditions Mémoire in Port-au-Prince, but returned to Quebec in 2001, and there in 2003 set up Mémoire d'encrier, an independent publishing house which specialises in Haitian literature.

In recent years, Haitian literature has drifted from Quebec to Paris. Yanick Lahens is now with a small Parisian publisher, Sabine Wespieser. Frankétienne's play Le Piège was published by Riveneuve éditions in Paris. Dany Laferrière has moved to Parisian publisher Grasset, owned by the global conglomerate Lagardère, and was elected to the Académie française in 2013. Increasingly, Haitian writers have become the main stars on the French literary circuit in Paris, and especially at the annual Étonnants voyageurs festival in Saint-Malo, Brittany, which has now become the biggest French literary festival ${ }^{19}$. The earthquake struck on the eve of the Haitian edition of the Étonnants voyageurs festival in Port-au-Prince, meaning that all of Haiti's main writers, including those resident abroad, as well as members of the French literary elite were gathered in Haiti, and consequently experienced the earthquake. Laferrière and Saint-Éloi's intertwined and overlapping 2010 accounts of the earthquake, Tout bouge autour de moi and Haïti, kenbe la! $!^{20}$, tell the story of the interrupted literary festival.

14 These developments have created new opportunities for Laferrière to republish his back catalogue, and have also led to opportunities to rewrite his previous works. Tout bouge autour de moi is typical in this respect. Two different versions of this book exist, but the original and changed versions were both published by Mémoire d'encrier in Quebec in 2010 and 2011. Laferrière-like serial self- publisher Frankétienne-chooses to shape the rewriting/archiving process at the stage where he can have most control over the work himself. These changes are certainly not revisions demanded by the publisher, but authorial challenges to published fixity, which attempt to keep the work alive through serial publication. The archival turn in Haitian literature identified here places authorial emphasis on the subject of, and need for, archives, underscoring authorial autonomy in the shaping of the writers' own texts in ways which have previously been rarely considered. These earthquake narratives all tell different versions of the same story; in fact, they all tell different versions of their own stories as well. Obsessive reworking and the multiplicity of drafts and versions of these earthquake narratives enable preservation of the text as it produces its own archives.

On 12 January 2010 at 4:53 pm, Frankétienne had just a few minutes earlier finished rehearsing a new play called Melovivi in Haitian Kreyòl, or Le Piège. This play, written in November-December 2009, turned out to be premonitory because it depicts the two 
speakers as trapped under rubble after an earthquake-type disaster. In this play, there are two speakers-identified only as Speaker A and Speaker B-who remain anonymous in the aftermath of disaster, like the many nameless, uncounted, undocumented victims of the ensuing earthquake.

Everything remains anonymous and unspecific. There are no specific references in this play to a particular natural disaster; it could easily refer to any of the natural disasters which regularly attack Haiti, including hurricanes, landslides and floods. Dialogue between speakers A and B is what this play consists of, and both are alive and continue to speak "so that they do not die ${ }^{21}$ ". They may be trapped and facing death, but creative words are what keep them alive. Composed of eight sequences, the play also shows speakers A and B relishing their delight in inventive word- and sound-play, and the strings of new playful associations created, as with the final words of the entire play.

The typed manuscript forms the basis of the published version of Le Piège, which was published in time for the UNESCO première on 24 March 2010. Handwritten additions often accumulate energy, for example hyperbolic pleonasm amplifies the sense of apocalypse and growing ecological disaster in Haiti through a cumulative build-up of new strings of anaphora. There is one prominent page written in black marker pen about the planet as a many- evil-headed monster. This "Planète tête" sequence creates an incisive, lapidary effect, bringing the degree of planetary destruction to a forceful, climactic level.

18 A comparison of the manuscript of Le Piège with the 2010 published version, reveals that the play clearly evolves organically from one performance to the next. Garnel Innocent, the actor who played Speaker B against playwright-actor Frankétienne's Speaker A, recalls that improvisation was an important creative process during the play's elaboration, depending on the country in which the play was being performed ${ }^{22}$. In particular, the manuscript is full of numerous handwritten additions in the Kreyòl language, which were made before the Port-au-Prince performance in April 2010, especially musical components.

19 At the beginning and end, refrains of songs are added, with the whole play in the manuscript version starting and ending differently to the 2010 printed text. 
Signed first page of the manuscript for Le Piège,

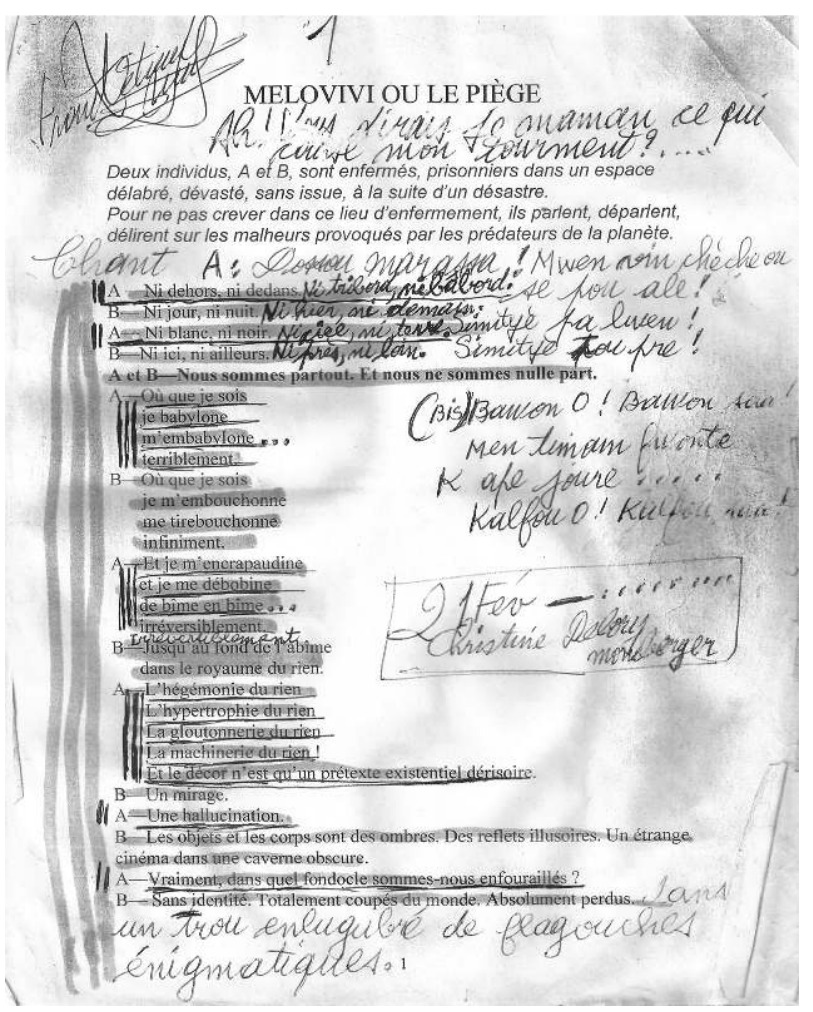

REPRODUCED WITH PERMISSION OF THE AUTHOR FRANKÉTIENNE.

Both the beginning and the end of the play invoke the "Dossou marassa", the powerful twins in the Haitian Vodou pantheon ${ }^{23}$. This has the effect of the play coming around full circle-or full spiral-to invoke Frankétienne's main literary metaphor and aesthetic tool, which has guided all his work from the mid-1960s onwards when he founded spiralisme, the only Haitian literary movement of note to emerge from under the Duvaliers. Inspired by this, nature's most oft-repeated paradigm, Frankétienne has always attempted to emulate the movement of the spiral in his own artistic work. In Le Piège, the play ends as it begins, with the speakers trapped: a spiral-like strategy of repetition, but with differences each time, like the progressive movement of the spiral. Speakers A and B present an archival inventory of voices post-disaster, saving stories from the ruins ${ }^{24}$. There are many points of intersection between this play of an apocalypse foretold and Frankétienne's Désastre (12 janvier 2010), painted just after the earthquake between 15 and 16 January 2010. This artwork, reproduced below, depicts a number of bodies and body parts lying underneath the rubble.

Reconstruction and the desire to remake Haiti are at the centre of these earthquake narratives. It is significant that a number of these texts have themselves been rewritten, or make prominent references to the idea of rewriting the text, as well as changing or rewriting Haiti itself. Most notably, Laferrière's Tout bouge autour de moi was extensively rewritten for a new "édition revue et augmentée" (revised and enlarged edition), which appeared in 2011, more than a year after first publication. Laferrière uses short fragments of text, which are then interspersed with many new fragments in 2011, and the occasional deletion. Such additions break up the narrative as they do the narrator's journey around Port-au-Prince following the earthquake. 


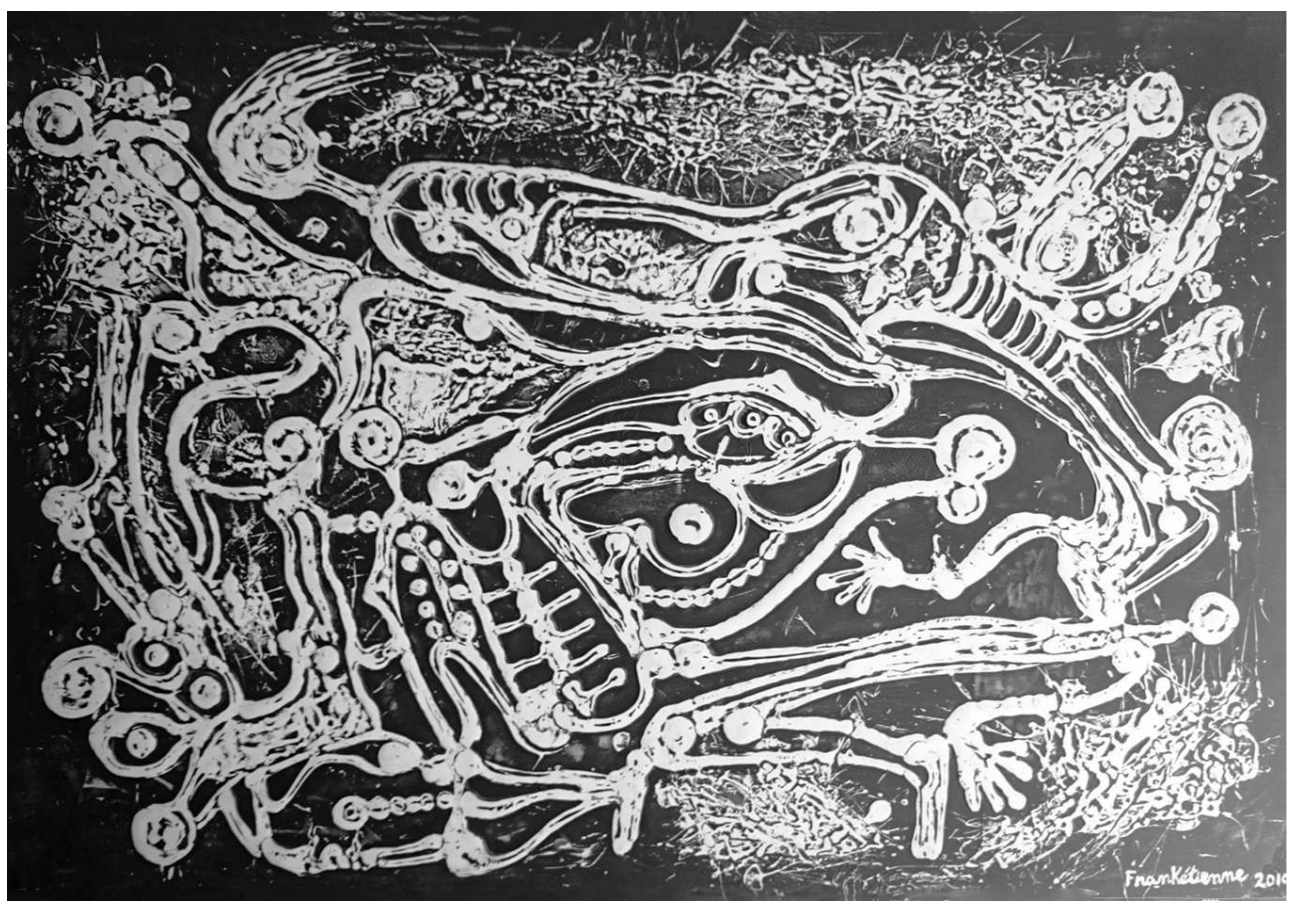

REPRODUCED WITH PERMISSION OF THE ARTIST.

Repeatedly, in what is added in Tout bouge autour de moi, the narrator and his fellowHaitians are described as being "hébétés", dazed or stupefied. There are descriptions of hotel guests immediately after the earthquake "turning round and round or sitting on the bed with a dazed look"25. In a short episode entitled "Le Lieu" (Place), Laferrière changes the ending considerably. Here the 2011 deletions are crossed out with strikethrough while the 2011 additions are in bold:

The fatal moment-16.03-which cut Haitian time in two. Henceforth there is a before and an after 12 January 2010. We are looking at Port-au-Prince with the dazed air of a child whose toy has just been accidentally tramped underfoot by an adult $^{26}$.

23 These witness accounts present the "nous" or "we" as dazed zombies. The origins of the myth of the zombie are Haitian, and like the mythical zombie figure, everyone is depicted as mort-vivant, like the living-dead, more dead than alive in the post-disaster circumstances. These 2011 changes suggest that the earthquake has in the event turned out to be a less decisive break with the past than Laferrière had initially feared ${ }^{27}$.

Much is added in the revised version, with almost half of the book from the episode "Return"28 onwards dedicated to returning to Haiti later in 2010 for Aunt Renée's funeral. One landmark of Port-au-Prince is highlighted in both the 2010 and 2011 versions of Tout bouge autour de moi: Frankétienne's partly destroyed house. This is a site which features prominently in both Laferrière and Saint-Éloi's narratives about visiting the city on the day after the earthquake. In the rewritten version of Tout bouge autour de moi, Laferrière adds an episode titled "La Stratégie de Frankétienne" (81-82). Here, there is emphasis on the rebuilding work that Frankétienne is having done to his house involving the mounting of concrete pillars, which Frankétienne is then painting "in the style of Basquiat" and in a style which is also reminiscent for Laferrière of two Haitian artists: Tiga and Saint-Brice. It was that first visit to Frankétienne's house 
which convinced Laferrière and Saint-Éloi that Haitian culture could save Haiti. Now, even more in this new account of the visual and structural transformations of the dwelling, Laferrière signals that "the important thing is that Frankétienne is trying to make a work of art out of this disaster" 29 . Such projects are ultimately what gives new hope that alternative cultural reconstruction of Haiti can work, even in the aftermath of the most apocalyptic disaster.

Page from Yanick Lahens's manuscript Failles,

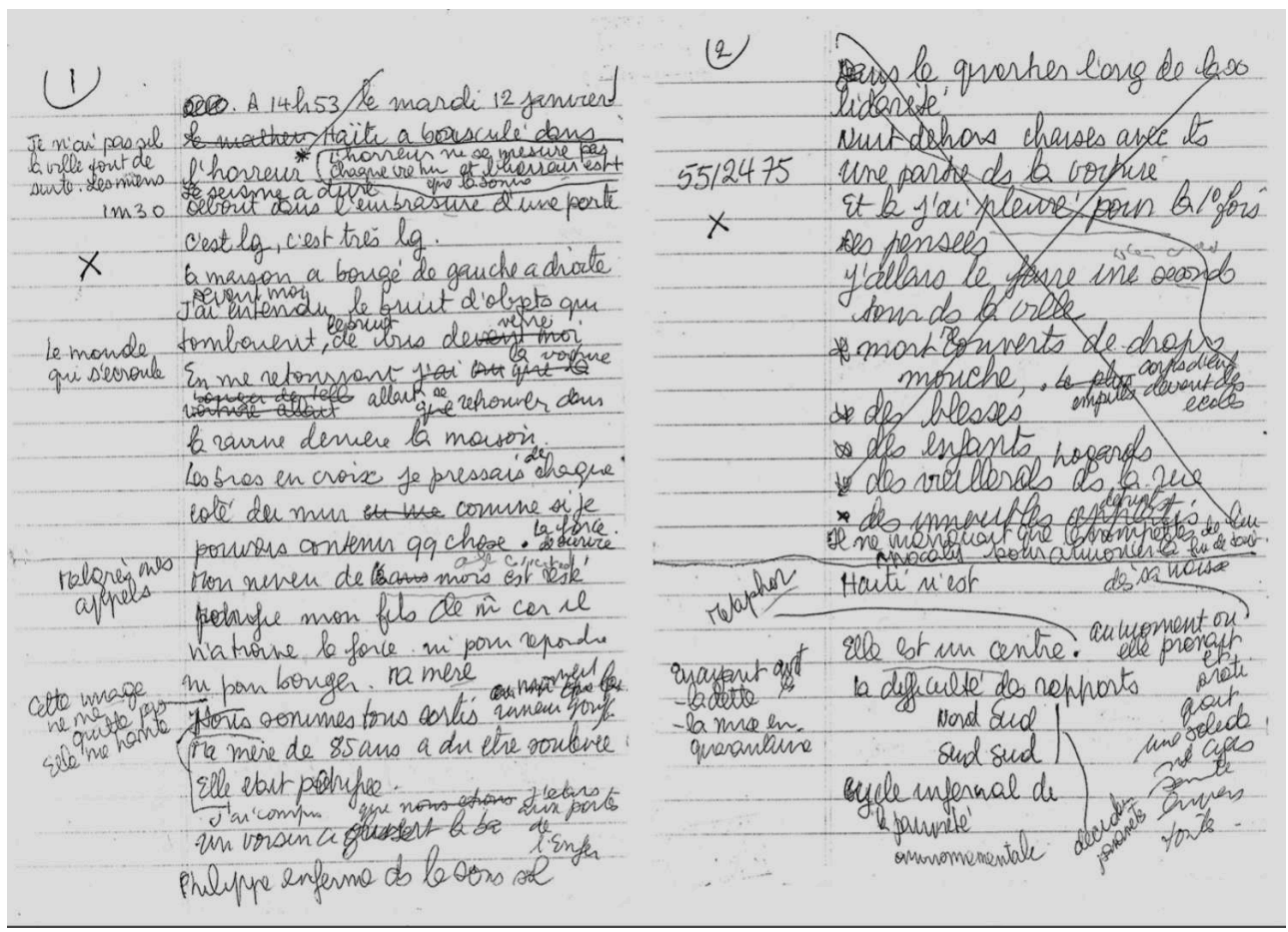

Reproduced with permission of the author Yanick Lahens.

Rewriting and archival impulses can be traced throughout Yanick Lahens's autobiographical account of the earthquake, Failles, and her novel Guillaume et Nathalie, which she was also writing when the earthquake struck, when we compare and contrast their manuscript and published versions. In the pages of the published Failles itself, Lahens recounts how she started to keep a diary from Wednesday, 13 January 2010 onwards "with a simple account of the facts and a description that I wanted to be the most precise possible about the damage ${ }^{30}$. What had already happened the day before was jotted down from memory. Much of the manuscript of Failles is written in diary form. Entries for each day are handwritten and consist of a few lines and key words. These handwritten diary pages are interspersed with hastily typed ones with typographical errors and without accents. Asterisks mark handwritten notes and statistics about the capital city Port-au-Prince in the earthquake aftermath.

Most of the typewritten pages in the Failles manuscript come from her other project, the novel she was working on before the earthquake struck, and which would ultimately become Guillaume et Nathalie when published in 2013. At this stage, only the broad lines of the novel are sketched out; for example, she refers to the "beginning of the novel" and writes:

I abandoned $\mathrm{X}$ and $\mathrm{Y}$, the characters of the novel I was getting ready to write. Some notes are scribbled down ... You will have understood that $X$ and $Y$ had a date in 
the area of Pacot which overlooks Port-au-Prince. I'm finding it difficult to find my characters unscathed in such a decor among the dust, the rubble, in the suffering of the wounded, in the still warm blood of the dead. I will need more time ${ }^{31}$.

One part of the Failles manuscript which has been considerably reworked and restructured is the description of the actual moment when the earthquake struck, with paragraphs renumbered to postpone the section about going around the city on the following day and seeing all the bodies; an order which makes more sense. Overwriting in a palimpsestic manner is a feature of the handwritten sections of both Frankétienne and Lahens's manuscripts. Their handwriting traces and retraces the same letters over and over in the handwritten manuscripts. In this way, even the very beginnings of these texts are predicated on rewriting and repetition.

Furthermore, there is a strong intertextual relationship between the published versions of Failles and Guillaume et Nathalie, which is also predicated on rewriting ${ }^{32}$. Interspersed with the text of Failles are many of her notes for her new novel to be entitled Guillaume et Nathalie. For this love story, which is also a love poem for the city of Port-au-Prince, Lahens writes in the published Failles of travelling to the apartment block up the hill in Pacot where she had always imagined the pair would meet and live. When the narrator reaches the spot, nothing remains; everything has turned to rubble and fallen down into a ravine ${ }^{33}$. Clearly, she imagines that the couple would be dead and buried in the earthquake. To block out this reality, she repeats the opening lines of her novel several times to make her characters exist again, not letting misfortune win.

Here, the yellow notebook containing the literary manuscript of the unfinished novel Guillaume et Nathalie is referred to constantly, with its opening words setting the scene of the main characters' first meeting being repeated over and over in the published version of Failles. These words start to resemble refrains from the manuscript intertext of the yellow notebook, through which Lahens brings Guillaume and Nathalie back into existence. Repetition plays an important role in Failles, which begins as a fairy tale: the first chapter heading is "Il était une fois une ville" (once upon a time there was a city). Repeated eight times, the phrase "Il était une fois une ville" starts off a series of reflections on the capital city Port-au-Prince; a fairy tale which quickly becomes dystopian once it becomes an account of the earthquake. Failles ends with an excerpt from the manuscript of Guillaume et Nathalie, and the description of the characters' first kiss. This final chapter 31 of Failles, headed "Je ne sais pas encore" (I still don't know), refers to the fate of her pair of characters whose fate in the future tense is not clear: "I still don't know what will become of Nathalie and Guillaume."

Lahens's next book was indeed the fictional love story of Guillaume et Nathalie, published in 2013. This book is marked by the earthquake paratextually. To end the book, there is an epilogue, which takes us from the closing moments of Nathalie and Guillaume's love story, which, we are told, was set in December 2009, towards the earthquake of 12 January 2010 at 4:53 p.m. Here the novel comes together with Failles, the autobiographical account of the earthquake, as it ends with the same memorable description of the earthquake-as-rapist who turns the body and the poverty of the citywoman Port-au-Prince inside-out and upside-down so that everything is on display. Another intersection with Failles comes in Guillaume et Nathalie when Guillaume listens to a Haitian seismologist on the radio talking about the imminence of an earthquake in Haiti before it happens ${ }^{34}$. 
31 An explicit reference to the actual earthquake also appears on the back cover of the book, tapping into interest generated in Haiti since the earthquake. The synopsis on the back cover informs us that "magnetised by each other, they [Guillaume et Nathalie] resist for a time and then ... an earthquake shakes Haiti's depths". Ultimately, this is somewhat misleading because the quake does not feature at all in the text proper of Guillaume et Nathalie. Whereas in Failles Lahens intimates that they die trapped under the rubble, no indication is given in Guillaume et Nathalie of the outcome for the two protagonists and this question is left more open.

32 Examining the making of these chronicles of the Haitian earthquake reveals rewriting to be a strategic device with an important performative component. It responds to the need for Haiti to be seen and represented properly. In part, this involves writing back to the saturation of standard-formula media images of Haiti in the aftermath of the 2010 earthquake. Gina Athena Ulysse in her book Why Haiti Needs New Narratives outlines her "alter(ed)native" post-earthquake performances including voices of Haitian people and offering their words for an alternative archive of 12 January $2010^{35}$.

Ulysse edited an archive of "Pawòl fanm sou douz janvye (Women's words on 12th January 2010)" for a special section of a 2011 issue of the journal Meridians ${ }^{36}$. She underlined the importance of collecting alternative quake archive stories from Haitians' own point of view, especially as evidence of how Haitians came to one another's aid, since "such stories were not the focus of popular media coverage". The focus in this work is on including and archiving their stories in order to challenge the narratives of the sensationalist media. While these archive stories fail to be representative across classes, Ulysse writes that they were not meant to be: "The intent was to offer readers a glimpse of the environment with nuances of how a few women lived through this moment, their responses and the continuous impact on their lives ${ }^{37}$."

Ulysse's contributions to this journal give voice to certain Haitian women whom she interviewed, including Solange Veillard David who is quoted as saying in Kreyòl, "Men pawòl nou sou douz janvye pou ashiv sa" (Here are our words on 12 January for this archive) ${ }^{38}$. She translates their words from Kreyòl into English. Other contributors to this archive are mainly educated women of Haitian descent. Why Haiti Needs New Narratives was published in the United States in three language versions: English, Kreyòl and French. There are no variants among these three versions, but the emphasis is placed strongly on the importance of archival strategies, and of passing on undocumented women's stories. In these post-earthquake times, Haitian representations of Haiti matter more than ever $^{39}$.

There is in Haitian writers' post-earthquake work a constant reassembly of fragments from their own texts, presenting in textual and artistic form a more hoped-for holistic picture of rebuilding and reconstruction, Haitian-style. Like a seismograph, fragmentary Haitian writing continues to record powerful aftershocks of the earthquake, and the story remains unfinished, generating new archives and narratives ${ }^{40}$.

36 This article has charted the aftershocks of this earthquake on Haitian literary and archival production. The 2010 Haitian earthquake left a definite imprint on Haitian culture, effectively leaving archival traces of its own. Especially since the earthquake, Haitian books can be thought of as resembling arks storing fragments of Haitian cultural heritage. In this context, the books themselves turn out to be archives. 
Archivisation is an extraordinary performative process which inscribes the archive documents often en abyme, that is, the records of the works' own making are contained inside the bodies of Haitian books themselves. Produced in this way is a type of archive which is recurrent. While literary works are often conceptualised as singular creations, there is an important repetition compulsion in these works, assuring the possibility of reproduction, which is so fundamental to the archive, according to Derrida ${ }^{41}$. It is the repetition principle at work in these reproduced and reproducible Haitian works which is effective democratisation, giving greater participation in, and access to, the archive, its constitution and its interpretation. Binding the archive in all its forms to every copy of the book resists annihilation through reproduction, producing more archive.

Archive fever has struck Haitian literature hard, and it is "en mal d'archive": in need of archives. Derrida's idea of a burning need for archives can be put in dialogue with Haitian writer Edwidge Danticat's observation that Haiti has always been tè glise or slippery ground, "stable one moment and crumbling the next", and that "Haiti has never been more slippery ground than after this earthquake" ${ }^{42}$. On this slippery ground of Haiti, literary archives and books are vulnerable and "slippery" themselves, but this slipperiness has a positive pole too. This article has argued that what we see in Haitian literature is a sort of archive, concerned with the future as well as a recording of the past. This taking place and gathering together of the Haitian archive texts takes the elements thrown into chaos by the earthquake into a new configuration, illuminating Haiti's rich cultural past, present and future. These works share the incompleteness and always unfinished qualities of the archive, and they search interminably to save the word and rebuild Haiti through its culture.

In addition to the actual archives-the Frankétienne and Lahens manuscriptsarchiving is also something that Haiti's creative writers do with content and form when writing and rewriting. An archive of this kind is a continuous production, always rereading the past in light of the present and the future. These Haitian earthquake narratives can be seen, following Stuart Hall, as an ongoing, never-completed project, which contradicts any possibility of completeness, with Haitian manuscripts and texts operating as a form of archive. These books are themselves made up of fragments and fissured writing, echoing the fissures fragmenting Haiti. Such fragments shatter any notion that "all" of the story of the earthquake can be told within the bounds of a single artistic work or book. Instead, Haitian writing, particularly since 2010, continues to produce powerful aftershocks of the disaster. Haitian writers and their readers sift through the necessarily incomplete fragments of these new narratives, performing a reassembly of the fragments, and piecing them together in manuscripts and versions of published texts: a creative reconstruction.

\section{APPENDIXES}

Acknowledements

I acknowledge the support of the Arts and Humanities Research Council (AHRC). 


\section{NOTES}

1. Frankétienne, Melovivi ou Le Piège (Paris: Riveneuve, 2010); Dany Laferrière, Tout bouge autour de moi (Montreal: Mémoire d'encrier, 2010; 2nd rev. ed., 2011) (further editions have been published with minimal changes); Dany Laferrière, Tout bouge autour de moi (Paris: Grasset, 2011; Paris: Librairie générale française, 2012); Yanick Lahens, Failles (Paris: Sabine Wespieser, 2010); Yanick Lahens, Guillaume et Nathalie (Paris: Sabine Wespieser, 2013); Gina Athena Ulysse, Why Haiti Needs New Narratives: A Post-Quake Chronicle (Middletown, CT: Wesleyan University Press, 2015).

2. I am grateful to the authors for sending me copies of these manuscripts.

3. See the innovative work on "Francophone manuscripts" at ITEM (Institut des textes et manuscrits modernes) at the CNRS, Paris, http://www.item.ens.fr/index.php?id $=484279$ (accessed 30 June 2016). On genetic criticism, see Almuth Grésillon, Éléments de critique génétique: Lire les manuscrits modernes (Paris: Presses Universitaires de France, 1994); Almuth Grésillon, La Mise en Euvre: itinéraires génétiques (Paris: CNRS, 2008); Dirk Van Hulle, Manuscript Genetics, Joyce's Know-How, Beckett's Nohow (Gainesville: University Press of Florida, 2008).

4. Rachel Douglas, Frankétienne and Rewriting: A Work in Progress (Lanham, MD: Lexington, 2009).

5. On archivisation, see Jacques Derrida, Archive Fever: A Freudian Impression, trans. Eric Prenowitz (Chicago: University of Chicago Press, 1996), II, 19; Helen Freshwater, "The Allure of the Archive", Poetics Today 24, no. 4 (2003): 724-58. On the "aura" of the object, see Walter Benjamin, The Work of Art in the Age of Mechanical Reproduction (London: Penguin, 2008), 1-50.

6. See Hal Foster, “An Archival Impulse”, October 110 (2004): 3-22.

7. Michel-Rolph Trouillot, Silencing the Past: Power and the Production of History (Boston: Beacon Press, 1995); Charles Forsdick, "Monuments, Memorials, Museums: Slavery Commemoration and the Search for Alternative Archival Spaces", Francosphères 3, no. 1 (2014): 81-98.

8. Laurent Dubois, "Maroons in the Archives: The Uses of the Past in the French Caribbean", in Archives, Documentation and Institutions of Social Memory, ed. Francis X. Blouin and William G. Rosenberg (Ann Arbor: University of Michigan Press, 2006), 291-300.

9. Derrida, Archive Fever, 91.

10. There is a postcolonial Derrida who is an ally of decolonisation according to some, although others have taken Derrida to task for being apolitical, ahistorical, and for his excessive textualism. See Jane Hiddleston, "Derrida, Autobiography and Postcoloniality", French Cultural Studies 16, no. 3 (2005): 291-304; Michael Syrotinski, Deconstruction and the Postcolonial: At the Limits of Theory (Liverpool: Liverpool University Press, 2007); Abdelkebir Khatibi, Maghreb pluriel (Paris: Denoël, 1983); Benita Parry, "Signs of Our Times: A Discussion of Homi Bhabha's The Location of Culture", Third Text 28-29 (1994): 5-24; Aijaz Ahmad, In Theory: Classes, Nations, Literatures (London: Verso, 1992).

11. Achille Mbembe, "The Power of the Archive and Its Limits", in Refiguring the Archive, ed. Carolyn Hamilton et al. (Dordrecht: Kluwer, 2002), 19-26; Stuart Hall, "Constituting an Archive", Third Text 15 (2001): 89-92. See also Joan M. Schwartz and Terry Cook, "Archives, Records, and Power: The Making of Modern Memory", Archival Science 2 (2002): 1-19.

12. Martin Munro, Writing on the Fault Line: Haitian Literature and the Earthquake of 2010 (Liverpool: Liverpool University Press, 2015), 23-24; Mark Anderson, Disaster Writing: The Cultural Politics of Catastrophe in Latin America (Charlottesville: University of Virginia Press, 2011), 146.

13. See the Haitian Cultural Recovery Project website: http://haiti.si.edu/ (accessed 30 June 2016). See Mark Schuller and Pablo Morales, Tectonic Shifts: Haiti Since the Earthquake (Sterling, VA: Kumarian Press, 2012) on the lack of reliable statistics for Haiti before, as well as after the quake. 14. Hall, "Constituting an Archive", 89-92. 
15. Robert Fraser, Book History through Postcolonial Eyes: Rewriting the Script (London: Routledge, 2008).

16. George Lamming, The Pleasures of Exile (London: Michael Joseph, 1960); Ngũgĩ wa Th iong'o, Decolonising the Mind (Oxford, Nairobi and Portsmouth: James Currey, EAEP and Heinemann, 1986); Ngũgĩ wa Thiong'o, Moving the Centre (Oxford, Nairobi and Portsmouth: James Currey, EAEP and Heinemann, 1993); Gail Low, "Local and Metropolitan Publishing", The Routledge Companion to Anglophone Caribbean Literature, ed. Michael Bucknor and Alison Donnell (London: Routledge, 2011), 616-25.

17. Graham Huggan, The Postcolonial Exotic: Marketing the Margins (London: Routledge, 2001); Sarah Brouillette, Postcolonial Writers in the Global Literary Marketplace (Basingstoke: Palgrave Macmillan, 2007).

18. Low, "Local and Metropolitan Publishing"; Ruth Bush, Publishing Africa in French: Literary Institutions and Decolonization 1945-1967 (Liverpool: Liverpool University Press, 2016).

19. See Grégoire Leménager, "Comment Étonnants voyageurs est devenu le plus gros festival littéraire français du monde”, Nouvel Observateur, 21 May 2015, http://bibliobs.nouvelobs.com/ actualites/20150521 (accessed 30 June 2016).

20. Rodney Saint-Éloi, Haïti, kenbe la! (Neuilly-sur-Seine: Lafon, 2010).

21. Frankétienne, Le Piège, 17.

22. Garnel Innocent, email message to author, 7 May 2016. The play has been performed in France, the United States, Haiti, Canada and Switzerland, among other places.

23. On the notion of the twins and "dossou", see Maximilien Laroche, Le marron et la dossa (SainteFoy, Quebec: GRELCA, 1988), 155-235; Maximilien Laroche, “Dézafi après Duvalier”, Dérives 53-54 (1987): 100. See also Florence Bellande-Robertson, e Marassa Concept in Lilas Desquiron's "Reflections of Loko Miwa" (Dubuque, IA: Kendall/Hunt, 1999), 4-5.

24. There are resonances with the archival inventory of the spoken word housed online by the Haiti memory project. See http://haitimemoryproject.org/ (accessed 1 May 2016).

25. Laferrière, Tout bouge autour de moi, 2010 ed., 26; 2011 ed., 13 (my italics).

26. Ibid., 2010 ed., 34; 2011 ed., 17.

27. See also Munro, "Writing on the Fault Line", 38-42.

28. Laferrière, Tout bouge autour de moi, 2011 ed., 66.

29. Ibid., 82.

30. Lahens, Failles, 91.

31. Lahens, Failles manuscript.

32. See Laura Loth, “(Re)Reading the Ruins: Yanick Lahens's Post-Earthquake Narrative Revisions", Women in French Studies 23 (2015): 125-42.

33. Lahens, Failles, 52-53.

34. Lahens, Guillaume et Nathalie, 30-31.

35. Ulysse, Why Haiti Needs New Narratives, 72.

36. Gina Athena Ulysse, ed., "Part 2: From the Archives", Meridians 11, no. 1 (2011).

37. Gina Athena Ulysse, "Pawòl fanm sou douz janvye (Women's Words on January 12th, 2010)": Introduction, Meridians 11, no. 1 (2011): 91-97; see http://muse.jhu.edu/arti cle/463990.

38. Ibid., 96.

39. See Gina Athena Ulysse, "Why Representations of Haiti Matter More Now an Ever", in Ulysse, Why Haiti Needs New Narratives, 26-32.

40. Also see the anthology of Haitian responses on reconstruction: Pierre Buteau, Rodney SaintÉloi, and Lyonel Trouillot, eds., Refonder Haïti (Montreal: Mémoire d'encrier, 2010).

41. See Derrida, Archive Fever, 11, 20.

42. Edwidge Danticat, Create Dangerously: e Immigrant Artist at Work (Princeton, NJ: Princeton University Press, 2010), 157-58. 


\section{AUTHOR}

RACHEL DOUGLAS

Lecturer in Francophone postcolonial studies at the University of Liverpool 